\section{Diagnostikk og behandling av autoimmun hepatitt}

\author{
KLINISK OVERSIKT

\section{METTE VESTERHUS} \\ E-post: mette.namdal.vesterhus@haraldsplass.no \\ Medisinsk avdeling \\ Haraldsplass Diakonale Sykehus \\ og \\ Klinisk institutt 2 \\ Universitetet i Bergen \\ Hun har bidratt med idé, litteratursøk, utarbeiding av tabell 2 samt vært hovedansvarlig for utforming \\ og revisjon av manus. \\ Mette Vesterhus er spesialist i indremedisin og i fordøyelsessykdommer, overlege og \\ førsteamanuensis. Hun er prosjektleder for Nasjonalt nettverk for autoimmune leversykdommer. \\ Forfatteren har fylt ut ICMJE-skjemaet og oppgir ingen interessekonflikter.
}

\section{KRISTINE WIENCKE}

Norsk senter for primær skleroserende cholangitt (NoPSC)

og

Seksjon for fordøyelsessykdommer

Klinikk for kirurgi, inflammasjonsmedisin og transplantasjon

Oslo universitetssykehus, Rikshospitalet

Hun har bidratt med utarbeiding av tabell 3 samt utforming av deler av manus, revisjon og godkjenning av innsendte manus.

Kristine Wiencke er spesialist i indremedisin og i fordøyelsessykdommer og seksjonsoverlege. Hun er styremedlem i Nasjonalt nettverk for autoimmune leversykdommer.

Forfatteren har fylt ut ICMJE-skjemaet og oppgir ingen interessekonflikter.

\section{JOHN WILLY HAUKELAND}

Gastromedisinsk avdeling

Oslo universitetssykehus, Ullevål

Han har bidratt med utarbeiding av tabell 2 samt utforming av deler av manus, revisjon og godkjenning av innsendte manus.

John Willy Haukeland er spesialist i indremedisin og i fordøyelsessykdommer og overlege. Han er styremedlem Norsk gastroenterologisk forenings interessegruppe for leversykdommer. Forfatteren har fylt ut ICMJE-skjemaet og oppgir ingen interessekonflikter.

\section{SVEIN OSKAR FRIGSTAD}

Medisinsk avdeling

Bærum sykehus, Vestre Viken

Han har bidratt med utarbeiding av tabell 1 samt utforming av deler av manus, revisjon og godkjenning av innsendte manus.

Svein Oskar Frigstad er spesialist i indremedisin og i fordøyelsessykdommer og seksjonsoverlege. Han er styremedlem i Nasjonalt nettverk for autoimmune leversykdommer.

Forfatteren har fylt ut ICMJE-skjemaet og oppgir ingen interessekonflikter. 
Medisinsk avdeling

Stavanger universitetssjukehus

Han har bidratt med utarbeiding av tabell 2 samt utforming av deler av manus, revisjon og godkjenning av innsendte manus.

Lars Normann Karlsen er spesialist i indremedisin og i fordøyelsessykdommer og seksjonsoverlege.

Han er styremedlem i Nasjonalt nettverk for autoimmune leversykdommer.

Forfatteren har fylt ut ICMJE-skjemaet og oppgir ingen interessekonflikter.

\section{KRISTIN KAASEN JØRGENSEN}

Gastromedisinsk avdeling

Akershus universitetssykehus

Hun har bidratt med utarbeiding av tabell 3 samt utforming av deler av manus, revisjon og godkjenning av innsendte manus.

Kristin Kaasen Jørgensen er spesialist i indremedisin og i fordøyelsessykdommer og seksjonsoverlege.

Hun er leder av Norsk gastroenterologisk forenings interessegruppe for leversykdommer og

styremedlem i Nasjonalt nettverk for autoimmune leversykdommer.

Forfatteren har fylt ut ICMJE-skjemaet og oppgir ingen interessekonflikter.

\section{TRINE FOLSERAAS}

Norsk senter for primær skleroserende cholangitt (NoPSC)

og

Seksjon for fordøyelsessykdommer

Klinikk for kirurgi, inflammasjonsmedisin og transplantasjon

Oslo universitetssykehus, Rikshospitalet

Hun har bidratt med idé, utforming av manus, utarbeiding av tabell 3 samt revisjon og godkjenning av innsendte manus.

Trine Folseraas er spesialist i indremedisin og i fordøyelsessykdommer, overlege og

forskningsgruppeleder.

Forfatteren har fylt ut ICMJE-skjemaet og oppgir ingen interessekonflikter.

Autoimmun hepatitt er en kronisk leversykdom som ubehandlet kan føre til levercirrhose og leversvikt. Majoriteten av pasientene responderer godt på standard immunsuppressiv behandling, men noen opplever bivirkninger eller manglende behandlingseffekt.

Diagnostikk, evaluering av behandlingsrespons og valg av annenlinjebehandling kan være utfordrende. Vi sammenfatter her oppdatert kunnskap om diagnostikk og behandling av pasienter med komplisert autoimmun hepatitt.

Autoimmun hepatitt (AIH) er en kronisk autoimmun leversykdom med ukjent etiologi, som ubehandlet kan progrediere til levercirrhose og leversvikt $(1,2)$. Flere kvinner enn menn rammes (ca.3:1). Diagnosen stilles typisk i tenårene eller 40-6o års alder, men i $\emptyset$ kende grad også hos personer over 65 år. Sykdommen er definert som sjelden, med punktprevalens 16,9/10o ooo i Norge i 1995 (3). Det rapporteres imidlertid om økende forekomst i flere land (4).

Immunsuppressiv behandling med kortikosteroider har oftest god effekt (5) og er det viktigste medikamentet for å indusere remisjon. Azatioprin, med eller uten kortikosteroider, er det viktigste medikamentet for å opprettholde remisjon. Imidlertid er det utfordringer knyttet til langvarig behandling med disse medikamentene. Grundig oppfølging og individtilpasset behandling i tett samarbeid med fastlegen er viktig, både med tanke på bivirkninger og behandlingseffekt.

Pasienter med autoimmun hepatitt har samlet en $ø$ kt risiko for levertransplantasjon eller tidlig død. Dette kan dels være knyttet til forsinket behandlingsstart som følge av etablering av diagnose først ved avansert sykdomsstadium (ca. $25 \%$ har cirrhose og/eller dekompensert leversykdom ved diagnosetidspunktet) (4). En annen årsak kan være utilstrekkelige behandlingstiltak hos pasienter som ikke oppnår full remisjon ved standardbehandling.

Vi presenterer her anbefalinger for diagnostikk og behandling ved autoimmun hepatitt. Artikkelen er basert på et ikke-systematisk søk i databasen PubMed, internasjonale anbefalinger og forfatternes kliniske erfaring. 


\section{Hvordan stilles diagnosen?}

Det kliniske bildet ved autoimmun hepatitt er mangfoldig. Forhøyede transaminaser (aspartataminotransferase (ASAT), alaninaminotransferase (ALAT)) er ofte det som leder til mistanke og utredning av tilstanden, men inngår ikke i de diagnostiske kriteriene.

Forhøyede leverprøver oppdages oftest hos fastlegen. Det er viktig at vedvarende forhøyede leverprøver, uansett nivå, utredes slik at sykdom oppdages. Ved forhøyede transaminaser bør fastlegen kontrollere virusserologi med tanke på virushepatitt, immunglobuliner og autoantistoffer før henvisning til gastroenterolog. De fleste pasientene har ved diagnosetidspunktet ingen eller kun uspesifikke symptomer (utmattelse (fatigue), nedsatt allmenntilstand, øvre høyre magesmerter, kvalme, kløe og/eller leddsmerter) (4, 6, 7). Hos et mindretall (ca. $25 \%$ ) manifesterer sykdommen seg som akutt hepatitt med ikterus og kvalme (1).

Leverbiopsi er nødvendig for å stille diagnosen og skal tas før behandling, da behandlingen kan kamuflere histologiske funn og vanskeliggjøre diagnostikken. Typiske histologiske funn ved sykdommen er inflammatorisk aktivitet i portalområdene som sprer seg innover i leverlobuli (interfasehepatitt) og gir økt mengde plasmaceller (1). De histologiske funnene er imidlertid ikke spesifikke for autoimmun hepatitt, og diagnosen baserer seg også på forhøyet serum-immunglobulin G (IgG) og/eller moderat eller høyt titer av visse autoantistoffer (kjerneantistoffer (ANA), glatt muskulatur-antistoffer (SMA)/anti-f-actin, eventuelt anti-LKM (lever-nyre-mikrosom)-1 og anti-SLA (anti-løselige leverantigen)) (1). Anti-SLA kan iblant være det eneste positive autoantistoffet. Dette bør tas dersom de andre autoantistoffene er negative eller inkonklusive. Virale hepatitter skal utelukkes. Kroniske leversykdommer som kan representere differensialdiagnoser og/eller komorbiditet (f.eks. ikke-alkoholisk fettleversykdom, som ses hos ca. $1 / 4$, eller annen autoimmun leversykdom) bør identifiseres.

International Autoimmune Hepatitis Study Group har publisert to skåringsverktøy for diagnostikk av autoimmun hepatitt $(8,9)$. Verktøyene er godt validert og kan være til god hjelp, men diagnosen autoimmun hepatitt baseres i praksis på en samlet klinisk vurdering (10).

En usikker diagnose styrkes hvis behandlingsfors $ø \mathrm{k}$ med steroider gir klar biokjemisk respons (8). Legemiddelindusert leverskade er en viktig differensialdiagnose som også kan respondere på steroider. Ved samtidig kronisk viral hepatitt er det i praksis vanskelig å si om det også foreligger autoimmun hepatitt. I slike tilfeller bør diagnostikk med tanke på autoimmun hepatitt, inkludert leverbiopsi, repeteres når den virale hepatitten er behandlet og i remisjon.

\section{Standardbehandling}

\section{BEHANDLINGSINDIKASJON}

Alle pasienter med aktiv autoimmun hepatitt skal i utgangspunktet behandles for å unngå progrediering til cirrhose, leversvikt, hepatocellulært karsinom og eventuelt behov for levertransplantasjon (1). Også pasienter med cirrhose bør behandles. Å avstå fra behandling i de helt eldre aldersgruppene kan være riktig, særlig ved mild sykdomsaktivitet (ALAT $<3 \times$ $\emptyset$ vre referansegrense) uten avansert fibrose eller symptomer, da tiårsoverlevelsen er høy (67-90 \%) og behandling ofte forbundet med bivirkninger $(1,11)$. Hos yngre pasienter med mild sykdomsaktivitet er behandling oftest indisert. Det kan iblant være aktuelt å avvente behandlingsoppstart ved spontan klinisk, laboratoriemessig og histologisk remisjon (hepatittaktivitetsindeks < 4/18) (1). For å oppdage subklinisk sykdomsprogrediering anbefales blodprøver hver 3.-6. måned.

\section{INDUKSJONSBEHANDLING}

Standardbehandling for autoimmun hepatitt er kombinasjonsbehandling med prednisolon og azatioprin i tråd med internasjonale retningslinjer (1). Det anbefales å starte 
med prednisolon i monoterapi med blodprøvekontroll etter to uker. Deretter legges azatioprin til. Denne strategien muliggjør evaluering av behandlingsrespons uten tolkningsforstyrrelser av eventuell azatioprinindusert hepatotoksisitet. Standard induksjonsbehandling er prednisolon $0,5-1 \mathrm{mg} / \mathrm{kg}(1)$, i praksis ofte rundt $40 \mathrm{mg}$, med justering primært knyttet til høy alder, spesielt høy eller lav vekt, sykdomsaktivitet og tidligere bivirkninger.

De aller fleste oppnår tydelig klinisk respons med fall av transaminaser i løpet av få uker med denne behandlingen. IgG-nivået faller noe langsommere. Det er viktig å overvåke og tilpasse behandlingen individuelt avhengig av biokjemisk respons og bivirkninger. Azatioprin startes på $50 \mathrm{mg}$ og trappes opp til 1-2 $\mathrm{mg} / \mathrm{kg}$ parallelt med at prednisolon trappes ned. Tiopurinmetyltransferase (TPMT) bør måles før oppstart. Induksjonsbehandling med azatioprin alene er ikke anbefalt (12-14). Prednisolon som monoterapi kan være et alternativ for pasienter der azatioprin er kontraindisert (f.eks. ved nedsatt TPMT-aktivitet, malignitet, oppstart under graviditet), men krever oftest høyere dose og fører ikke alltid til full remisjon.

\section{VEDLIKEHOLDSBEHANDLING}

Når pasienten er i stabil remisjon, er målet å gå over til azatioprin i monoterapi (1). Det er viktig å ikke trappe ned for fort, men dra nedtrappingen ut i tid for de laveste dosene. Prednisolon i lav dose som monoterapi kan iblant være et alternativ. Dersom remisjon ikke opprettholdes med monoterapi, anbefales kombinasjonsbehandling med azatioprin og lavest mulig dose prednisolon.

\section{ALTERNATIV FØRSTELINJEBEHANDLING}

Kombinasjonsbehandling med budesonid ( $9 \mathrm{mg} / \mathrm{dag}$ ) og azatioprin har tilsvarende effekt og mindre bivirkninger sammenliknet med standardbehandling. Denne kan forsøkes ved moderat sykdomsaktivitet og steroidbivirkninger, eksempelvis osteoporoseutvikling eller hyperglykemi/diabetes $(1,15)$. Vedlikeholdsdosen er uavklart. Budesonid bør ikke brukes ved cirrhose på grunn av risiko for nedsatt effekt ved portosystemisk shunting og nedsatt førstepassasjemetabolisme i leveren.

\section{BEHANDLINGSMÅL}

Behandlingsmålet er klinisk, biokjemisk og histologisk remisjon. I praksis vil det si normalisering av både transaminaser og IgG. Biokjemisk respons er assosiert med lav risiko for fibroseprogrediering. Pasienter i denne gruppen kan over tid oppnå regress av leverfibrose. Dersom biokjemisk remisjon ikke oppnås ved maksimale doser og etter nøye vurdering av adherens, bør det gjøres ny utredning med tanke på komorbiditet (f.eks. alkoholisk eller ikke-alkoholisk steatohepatitt, primær biliær kolangitt eller primær skleroserende kolangitt). Ved tvil om diagnosen bør ny leverbiopsi vurderes. Ved sann behandlingssvikt (ufullstendig respons) skal annenlinjebehandling vurderes.

\section{LIVSLANG BEHANDLING?}

Livslang behandling anbefales hos de fleste. Avslutning av behandling må veies opp mot den høye risikoen for residiv ( 80 \% innen ett år). Histologisk remisjon oppnås betraktelig senere enn biokjemisk remisjon, og et eventuelt seponeringsfors $ø \mathrm{k} b ø r$ ikke gjøres før pasienten har hatt stabil biokjemisk remisjon i minst to år under lavdosebehandling. Leverbiopsi bør vurderes før seponeringsfors $ø$, med mindre ALAT ligger i nedre halvdel av normalområdet og IgG er < 12 (1). Livslang oppfølging kreves.

\section{Annenlinjebehandling}

Før iverksetting av annenlinjebehandling bør man sikre seg at standardbehandlingen er optimalisert (tabell 1). Et mindretall av pasientene har behov for annenlinjebehandling (tabell 2) $(1,2,12)$. 
Tabell 1

Optimalisering av standardbehandling ved autoimmun hepatitt. Anbefalinger er basert på European Association for the Study of the Liver (1) og Lohse og medarbeidere (12).

\begin{tabular}{|ll|}
\hline Tilfelle & Anbefaling \\
\hline $\begin{array}{l}\text { Ved bivirkninger av } \\
\text { azatioprin }\end{array}$ & Sjekk 6-tioguaninnukleotider/ \\
& matriksmetalloproteinaser samt genotype av \\
& tiopurinmetyltransferase dersom dette ikke er gjort tidligere \\
& Ved kvalme: vurder å redusere dosen eller skifte til \\
& merkaptopurin (halv dose) \\
& Ved pankreatitt eller cytopeni: seponer behandlingen \\
\hline $\begin{array}{l}\text { Ved utilstrekkelig } \\
\text { effekt av azatioprin }\end{array}$ & Sjekk for manglende etterlevelse (lave verdier av 6- \\
& tioguaninnukleotider og matriksmetalloproteinaser) \\
& Ved lav 6-tioguaninnukleotider/høy matriksmetalloproteinaser: \\
& 100 mg allopurinol \\
\hline Ved bivirkninger av & Trapp ned til lavest mulig vedlikeholdsdose \\
prednisolon & Vurder å skifte behandling til budesonid: 6 mg $\times 1$ er ofte \\
& tilstrekkelig som vedlikeholdsdose. Budesonid er kontraindisert \\
& ved levercirrhose \\
\hline
\end{tabular}

\section{Tabell 2}

Alternativ behandling ved autoimmun hepatitt når standardbehandling ikke har tilstrekkelig effekt eller ikke tolereres. Anbefalinger er basert på Lohse og medarbeidere (12).

\begin{tabular}{|cl|}
\hline Behandling & \multicolumn{1}{c|}{ Kommentarer } \\
\hline Ved intoleranse eller kontraindikasjoner for azatioprin \\
\hline Mykofenolatmofetil & Partiell eller komplett respons oppnås hos 39-84 \% (19) \\
& Dosering: 1-2 g per dag fordelt på to doser \\
& Bivirkninger: gastrointestinale, benmargsdepresjon \\
& m.m. \\
& Det er usikkert om effekten er like god hos ikke- \\
& respondere som hos intolerante for azatioprin \\
\hline Ved ufullstendig respons på standardterapi \\
\hline Takrolimus & Partiell eller komplett respons oppnås hos 29-88 \% (20, \\
& 21) \\
& Dosering: uavklart. En ny konsensusrapport (12) foreslår \\
& en standardisert startdose på 0,1 mg/kg to ganger \\
& daglig med mål om bunnkonsentrasjon < 8 ng/ml, fulgt \\
& av nedtrapping styrt av bunnkonsentrasjon og effekt \\
& etter oppnådd remisjon \\
& Nyrefunksjonen bør evalueres før og under behandling \\
& Bivirkninger: nyresvikt. Vær oppmerksom på \\
interaksjoner \\
\hline Ciklosporin & Dosering: En ny konsensusrapport (12) foreslår en \\
& standardisert startdose på 2 mg/kg to ganger daglig \\
mapportert, men sparsom & med mål om bunnkonsentrasjon < 120 ng/ml, fulgt av \\
dokumentasjon av effekt & nedtrapping etter oppnådd remisjon \\
& Nyrefunksjonen bør evalueres før og under behandling \\
& Bivirkninger: nyresvikt \\
\hline Infliksimab, metotreksat, sirolimus, everolimus, \\
rituksimab, cyklofosfamid \\
\hline
\end{tabular}

'Optimalisering av behandling eller merkaptopurin kan forsøkes først, se tabell 1. Dersom behandling med mykofenolatmofetil er kontraindisert eller viser ufullstendig effekt, bør man vurdere alternativ annenlinjebehandling som for ufullstendig respons på standardterapi 
${ }^{2}$ Mykofenolatmofetil kan også forsøkes, men synes mindre effektivt for å indusere remisjon hos denne pasientgruppen. Behandlingsalternativ, dosering og effekt bør dokumenteres standardisert for å danne grunnlag for evidensbaserte anbefalinger

Ved intoleranse overfor azatioprin anbefales mykofenolatmofetil kombinert med prednisolon dersom tiltakene i tabell 1 ikke har effekt, dernest andre annenlinjemedikamenter $(1,16)$.

Ved ufullstendig respons på standardterapi der det i serum er tilfredsstillende nivåer av 6tioguaninnukleotider (6-TGN), den aktive metabolitten av azatioprin som står for $\emptyset$ nsket effekt, og der eventuell leverbiopsi viser histologisk aktiv autoimmun hepatitt, er annenlinjebehandling indisert og bør velges ut fra bivirkningsprofil (tabell 2). Mykofenolatmofetil kan forsøkes, men synes mindre effektivt for å indusere remisjon (17-19). Takrolimus og ciklosporin er de mest aktuelle alternativene, der den førstnevnte er best dokumentert (12, 20, 21). Sparsomme data foreligger for andre medikamenter (metotreksat, infliksimab, sirolimus, everolimus, rituksimab, cyklofosfamid).

Det gis ikke lenger individuell refusjon fra HELFO for annenlinjeterapi. Disse medikamentene skrives nå på h-resept etter godkjenning fra helseforetakets fagdirektør.

\section{Klinisk oppfølging}

Pasienter med autoimmun hepatitt har også ofte (14-44\%) annen autoimmun sykdom (22, 23). På diagnosetidspunktet bør det screenes for tyreoideasykdom og cøliaki, som forekommer hyppig sammen med sykdommen (2). Pasientene bør følges både i gastromedisinsk poliklinikk og hos fastlege, med oppmerksomhet rettet mot sykdomsaktivitet (transaminaser, IgG), komplikasjoner og komorbiditet (24). Leverstivhetsmåling med transient elastografi er et godt verktøy for å evaluere utvikling av avansert leversykdom og cirrhose. Målingene har liten verdi under pågående leverinflammasjon og må måles når pasienten er i remisjon. Vi fraråder alkoholbruk og tilråder at man er forsiktig med paracetamol ved aktiv hepatitt med transaminaser $>5$ ganger øvre normalområde.

Da sykdommen ofte debuterer hos unge pasienter, blir graviditet en problemstilling. Hos kvinner i fertil alder kan aktiv autoimmun hepatitt medføre amenoré og nedsatt fertilitet og er assosiert med for tidlig fødsel, vekstretardasjon hos fosteret samt $ø \mathrm{kt}$ sykdomsaktivitet, særlig i tiden etter fødsel (25). Biokjemisk remisjon bør tilstrebes i året før planlagt graviditet (2). Behandlingen bør kontinueres under svangerskapet.

\section{Levertransplantasjon}

Levertransplantasjon ved autoimmun hepatitt vurderes ved alvorlig forløp, dekompensert leversykdom eller hepatocellulært karsinom. Prognosen etter levertransplantasjon er god, men residiv kan imidlertid forekomme (2).

\footnotetext{
LITTERATUR:

1. European Association for the Study of the Liver. EASL Clinical Practice Guidelines: Autoimmune hepatitis. J Hepatol 2015; 63: 971-1004. [PubMed][CrossRef]

2. Mack CL, Adams D, Assis DN et al. Diagnosis and management of autoimmune hepatitis in adults and children: 2019 practice guidance and guidelines from the American Association for the study of liver diseases. Hepatology 2020; 72: 671-722. [PubMed][CrossRef]

3. Boberg KM, Aadland E, Jahnsen J et al. Incidence and prevalence of primary biliary cirrhosis, primary sclerosing cholangitis, and autoimmune hepatitis in a Norwegian population. Scand J Gastroenterol 1998; 33: 99-103. [PubMed][CrossRef]
}

4. Grønbæk L, Vilstrup H, Jepsen P. Autoimmune hepatitis in Denmark: incidence, prevalence, 
prognosis, and causes of death. A nationwide registry-based cohort study. J Hepatol 2014; 60: 612-7. [PubMed][CrossRef]

5. Cook GC, Mulligan R, Sherlock S. Controlled prospective trial of corticosteroid therapy in active chronic hepatitis. Q J Med 1971; 40: 159-85. [PubMed][CrossRef]

6. Werner M, Prytz H, Ohlsson B et al. Epidemiology and the initial presentation of autoimmune hepatitis in Sweden: a nationwide study. Scand J Gastroenterol 2008; 43: 1232-40. [PubMed][CrossRef]

7. van Gerven NM, Verwer BJ, Witte BI et al. Epidemiology and clinical characteristics of autoimmune hepatitis in the Netherlands. Scand J Gastroenterol 2014; 49:1245-54. [PubMed][CrossRef]

8. Alvarez F, Berg PA, Bianchi FB et al. International Autoimmune Hepatitis Group Report: review of criteria for diagnosis of autoimmune hepatitis. J Hepatol 1999; 31: 929-38. [PubMed][CrossRef]

9. Hennes EM, Zeniya M, Czaja AJ et al. Simplified criteria for the diagnosis of autoimmune hepatitis. Hepatology 2008; 48:169-76. [PubMed][CrossRef]

10. Lohse AW. Recognizing autoimmune hepatitis: scores help, but no more. J Hepatol 2011; 54: 193-4. [PubMed][CrossRef]

11. Czaja AJ. Features and consequences of untreated type 1 autoimmune hepatitis. Liver Int 2009; 29: 816-23. [PubMed][CrossRef]

12. Lohse AW, Sebode M, Jørgensen MH et al. Second-line and third-line therapy for autoimmune hepatitis: A position statement from the European Reference Network on Hepatological Diseases and the International Autoimmune Hepatitis Group. J Hepatol 2020; 73: 1496-506. [PubMed][CrossRef]

13. Soloway RD, Summerskill WH, Baggenstoss AH et al. Clinical, biochemical, and histological remission of severe chronic active liver disease: a controlled study of treatments and early prognosis. Gastroenterology 1972; 63: 820-33. [PubMed][CrossRef]

14. Murray-Lyon IM, Stern RB, Williams R. Controlled trial of prednisone and azathioprine in active chronic hepatitis. Lancet 1973; 1: 735-7. [PubMed][CrossRef]

15. Manns MP, Woynarowski M, Kreisel W et al. Budesonide induces remission more effectively than prednisone in a controlled trial of patients with autoimmune hepatitis. Gastroenterology 2010; 139: 1198-206. [PubMed][CrossRef]

16. Santiago P, Schwartz I, Tamariz L et al. Systematic review with meta-analysis: mycophenolate mofetil as a second-line therapy for autoimmune hepatitis. Aliment Pharmacol Ther 2019; 49: 830-9. [PubMed][CrossRef]

17. Roberts SK, Lim R, Strasser S et al. Efficacy and safety of mycophenolate mofetil in patients with autoimmune hepatitis and suboptimal outcomes after standard therapy. Clin Gastroenterol Hepatol 2018; 16: 268-77. [PubMed][CrossRef]

18. Sharzehi K, Huang MA, Schreibman IR et al. Mycophenolate mofetil for the treatment of autoimmune hepatitis in patients refractory or intolerant to conventional therapy. Can J Gastroenterol 2010; 24: 588-92. [PubMed][CrossRef]

19. Zachou K, Gatselis N, Papadamou G et al. Mycophenolate for the treatment of autoimmune hepatitis: prospective assessment of its efficacy and safety for induction and maintenance of remission in a large cohort of treatment-naïve patients. J Hepatol 2011; 55: 636-46. [PubMed][CrossRef]

2o. Efe C, Hagström H, Ytting H et al. Efficacy and safety of mycophenolate mofetil and tacrolimus as second-line therapy for patients with autoimmune hepatitis. Clin Gastroenterol Hepatol 2017; 15: 1950-1956.e1. [PubMed][CrossRef]

21. Pape S, Nevens F, Verslype $C$ et al. Profiling the patient with autoimmune hepatitis on calcineurin inhibitors: a real-world-experience. Eur J Gastroenterol Hepatol 2020; 32: 727-32. [PubMed][CrossRef]

22. Muratori P, Fabbri A, Lalanne C et al. Autoimmune liver disease and concomitant extrahepatic autoimmune disease. Eur J Gastroenterol Hepatol 2015; 27: 1175-9. [PubMed][CrossRef]

23. Bittencourt PL, Farias AQ Porta G et al. Frequency of concurrent autoimmune disorders in patients with autoimmune hepatitis: effect of age, gender, and genetic background. J Clin Gastroenterol 2008; 42:300-5. [PubMed][CrossRef]

24. Haraldsplass Diakonale Sykehus. Nasjonalt nettverk for autoimmune leversykdommer. 
https://www.haraldsplass.no/helsefaglig/forskning-og-utvikling/nasjonalt-nettverk-for-autoimmune-l eversykdommer Lest 28.4.2021.

25. Braga A, Vasconcelos C, Braga J. Autoimmune hepatitis and pregnancy. Best Pract Res Clin Obstet Gynaecol 2020; 68: 23-31. [PubMed][CrossRef]

Publisert: 22. juni 2021. Tidsskr Nor Legeforen. DOI: 10.4045/tidsskr.20.1045

Mottatt 21.12.2020, første revisjon innsendt 22.1.2021, godkjent 28.4.2021.

(ㅇ) Tidsskrift for Den norske legeforening 2020. Lastet ned fra tidsskriftet.no 